\title{
Carbon sequestration and its relation with some soil properties of East Kolkata Wetlands (a Ramsar Site): a spatio-temporal study using radial basis functions
}

\author{
Sudin Pal ${ }^{1,3} \cdot$ Sudip Manna ${ }^{2} \cdot$ Buddhadeb Chattopadhyay $^{3} \cdot$ \\ Subhra Kumar Mukhopadhyay ${ }^{3}$
}

Received: 13 April 2016/Accepted: 22 April 2016/Published online: 30 April 2016

(c) Springer International Publishing Switzerland 2016

\begin{abstract}
Determination of different environmental factors and their spatio-temporal variations is sparingly important theme in ecological science because the productivity of an ecosystem is regulated by these factors. Here in East Kolkata Wetland (EKW) through a web of canal the composite tannery effluent is discharged and these are productively used in the piscicultural and agricultural farming of this area. So, in concern of agro-piscicultural productivity it is very essential to know the present soil profile of EKW. Soil organic carbon (SOC) and some essential anions/nutrients like $\mathrm{F}, \mathrm{Cl}, \mathrm{NO}_{3}, \mathrm{PO}_{4}$ and $\mathrm{SO}_{4}$ in the agricultural/bank surface soils and bottom sediments are recorded from the seven different characteristic regions in EKW area. To describe precisely the variations of all these factors in spatio-temporal scale, the profile maps are constructed by using geostatistics. 1.03-2.25\% SOC in marginal bank soil and 1.26-2.42\% SOC in bottom soil are present in EKW area. Except $\mathrm{NO}_{3}$ all other measured anions are present higher concentration than normal level in EKW area and these have both positive and negative impact especially on the SOC concentration i.e. in carbon sequestration, anion-cation balance, ecotoxicity, nutrient availability of that area. Results of this study indicate that under proper management strategies of site specific use of
\end{abstract}

Sudin Pal

sudindgp1@gmail.com

1 Department of Chemical Engineering, Jadavpur University, Kolkata, West Bengal 700032, India

2 School of Oceanographic Studies, Jadavpur University, Kolkata, West Bengal 700032, India

3 Government College of Engineering and Leather Technology, Salt Lake, LB-III, Kolkata, West Bengal 700 098, India tannery effluent will reduce the fertilizer/manure cost of farmers. These will surely increase the contribution of leather industry in ecologically and ecological productivity of EKW Ecosystem.

Keywords East Kolkata Wetland · Geostatistical methods $\cdot$ Spatio-temporal variation $\cdot$ Spatial maps $\cdot$ Soil organic carbon

\section{Introduction}

Heterogeneity of soil properties is caused by several environmental factors. Apart from this, the soil properties are also changed with spatial and temporal scale. In case of wetland ecosystem the nutrient loadings and hydrologic modifications have an influence on the structure and function of the ecosystem as well as their spatial extent and distribution (Grunwald 2005; Richardson et al. 2005). So, it is important to know the compositions of essential nutrients in the soil, because all these nutrients have a major role in prokaryotic and eukaryotic growth, proper development of cell wall, cell division and elongation, metabolism and enzyme activity.

Here the East Kolkata Wetland (EKW) ecosystem, which is located in the eastern fringe of Kolkata city, is a Ramsar Site (no. 1208) of India. The EKW is extensively considered as a distinctive site which demonstrates the natural decline of toxicity by the biotic and abiotic components. From the Kolkata city the EKW receives untreated, massive nutrient rich raw tannery effluent, municipal and industrial wastewater and major part of those nutrients in composite wastewater are contributed by leather industry. Because in leather industry huge amount of different organic and inorganic chemicals are used. They are directly discharged into 
the environment and following several transformation process in soil system they are act as a nutrient and support rich and luxuriant primary producers and trap the unused carbon in different physicochemical state (Goswami et al. 2013; Pal et al. 2014). This wastewater has been also productively used in pisciculture and agriculture for the past several decades (Chatterjee et al. 2006; Pal et al. 2016). So, in the standpoint of agro-piscicultural production of EKW the information on soil characteristics is very important. Therefore, the explicit objective of this study is to identify the spatio-temporal changes of some important factors like Fluoride $(\mathrm{F})$, chloride $(\mathrm{Cl})$, Nitrate $\left(\mathrm{NO}_{3}\right)$, Phosphate $\left(\mathrm{PO}_{4}\right)$, Sulfate $\left(\mathrm{SO}_{4}\right)$ along with $\mathrm{SOC}$ by using geostatistics. Along with global positioning system (GPS) and geographic information system (GIS) this method is the powerful tools for understanding the spatio-temporal pattern of different environmental factors (Alexakis and Sarris 2014). The geostatistical method makes sure that the prediction error is minimum for the observed variables and it also gives poise for the prediction of unsampled locations (Schloeder et al. 2001). Though such landscape scale evaluation is applied in different parts of the globe (DeBusk et al. 2001; Bruland and Richardson 2005; Corstanje et al. 2006) but very little attention takes in India (Bhunia et al. 2016). In the areas of concern, this method provides valuable information, by quantifying the detrimental impact of anthropogenic activity and helps to design strategies for sustainable development, restoration and wise use of the wetland ecosystem. Also the interpolation and extrapolation maps will give the agrofishery farmers an idea about the present health of their production ground.

\section{Materials and methods}

\section{Study area and site description}

The East Kolkata Wetlands (Fig. 1; 12,741 ha; lat. 22 $33^{\prime}-$ $22^{\circ} 40^{\prime} \mathrm{N}$; long. $88^{\circ} 25^{\prime}-88^{\circ} 35^{\prime} \mathrm{E}$ ), was designated as "wetland of international importance" under the Ramsar Convention on August 19, 2002 (Ramsar Site no. 1208). The elevation profile of this area is ranged between 1-5 m with a gradual sloping towards south east. The average rainfall is $1000-1600 \mathrm{~mm}$ per year. The monsoon (July-October) is hot and humid (average humidity 87-98 \%), April-May are the hottest months (temperature $35-41{ }^{\circ} \mathrm{C}$ ) and December-January are the coolest $\left(10-16{ }^{\circ} \mathrm{C}\right)$. Here the wastewater from 600 different small industries, 538 tanneries and Kolkata municipality which contain huge amount of organic carbon are discharged into the EKW without any pre treatment (Pal et al. 2013). Seven different characteristic sites (on the basis of wastewater input and use), with roughly overlapping boundaries, are taken. Site
1: Raw tannery effluent passes through this area and located around $1 \mathrm{~km}$ away from the Tangra tannery agglomerate of Kolkata; Site 2: Tannery effluent-fed agricultural and pisciculture farms area; Site 3: In this area tannery effluent is mixed with municipal wastewater and other industrial effluents; Site 4: Composite wastewater-fed piscicultural and agricultural farming area at Chowbaga; Site 5: Kolkata Leather Complex (KLC), Bantala area where again tannery effluents are mixed with heterogeneous wastewater; Site 6: Agricultural field area with some agricultural runoff canals; Site 7: In this area composite effluents are finally mixed in the Kultigong River and it is nearly $40 \mathrm{~km}$ away from the Site 1 .

\section{Sampling and analysis}

The sampling has been done randomly around $3-4 \mathrm{~km}$ radius around each demarcated site in three consecutive seasons. Bank soils of the margin of the wastewater carrying canals and agricultural farms are collected from the upper $2 \mathrm{~cm}$ layer. The bottom soils of the wastewater carrying canals and wastewater fed fish ponds are also randomly collected from the same sites area. The collected samples are dried in hot air oven at $60^{\circ} \mathrm{C}$. The dried soil samples were handpicked of visible roots and leaves, grounded to powder and sieved with a $2-\mathrm{mm}$ sieve. The water samples were also collected from the seven sites in three consecutive seasons. The percentage of SOC was determined by Walkley-Black Method and total organic carbon (TOC) and total inorganic carbon (TIC) were measured by Lachat TOC-TN analyzer (Eaton et al. 2005). $\mathrm{F}, \mathrm{Cl}, \mathrm{NO}_{3}, \mathrm{PO}_{4}$ and $\mathrm{SO}_{4}$ were determined in Metrohm 761 Ion Exchange Chromatograph unit followed by standard methods (Jackson 2000). All the bar graphs with standard deviation were made by using of Origin 6.1 software and single linkage euclidian distance of different variables were performed by STATISTICAw 6.0 software.

\section{Generation of spatial maps}

The spatial distribution of SOC and anions available in the expanses of the EKW was mapped by using ArcGIS 9.3 software. Surface soil samples were used for the assessment of six different factors and the results were used in the inbuilt interpolation model in GIS environment. We used the radial basis functions and the functions are described by Bishop (1995). Further descriptions of radial basis functions and their relationships to splines and kriging can be found in Cressie (1993) and Chiles and Delfinder (1999).

The radial basis function fits mathematical function to measured points and makes no assumption about the data. The interpolator for each sample location uses $\mathrm{n}$ basis functions and is a linear combination of functions, 
Fig. 1 Study site map of East Kolkata Wetland Ecosystem (India and West Bengal maps are not in scale)

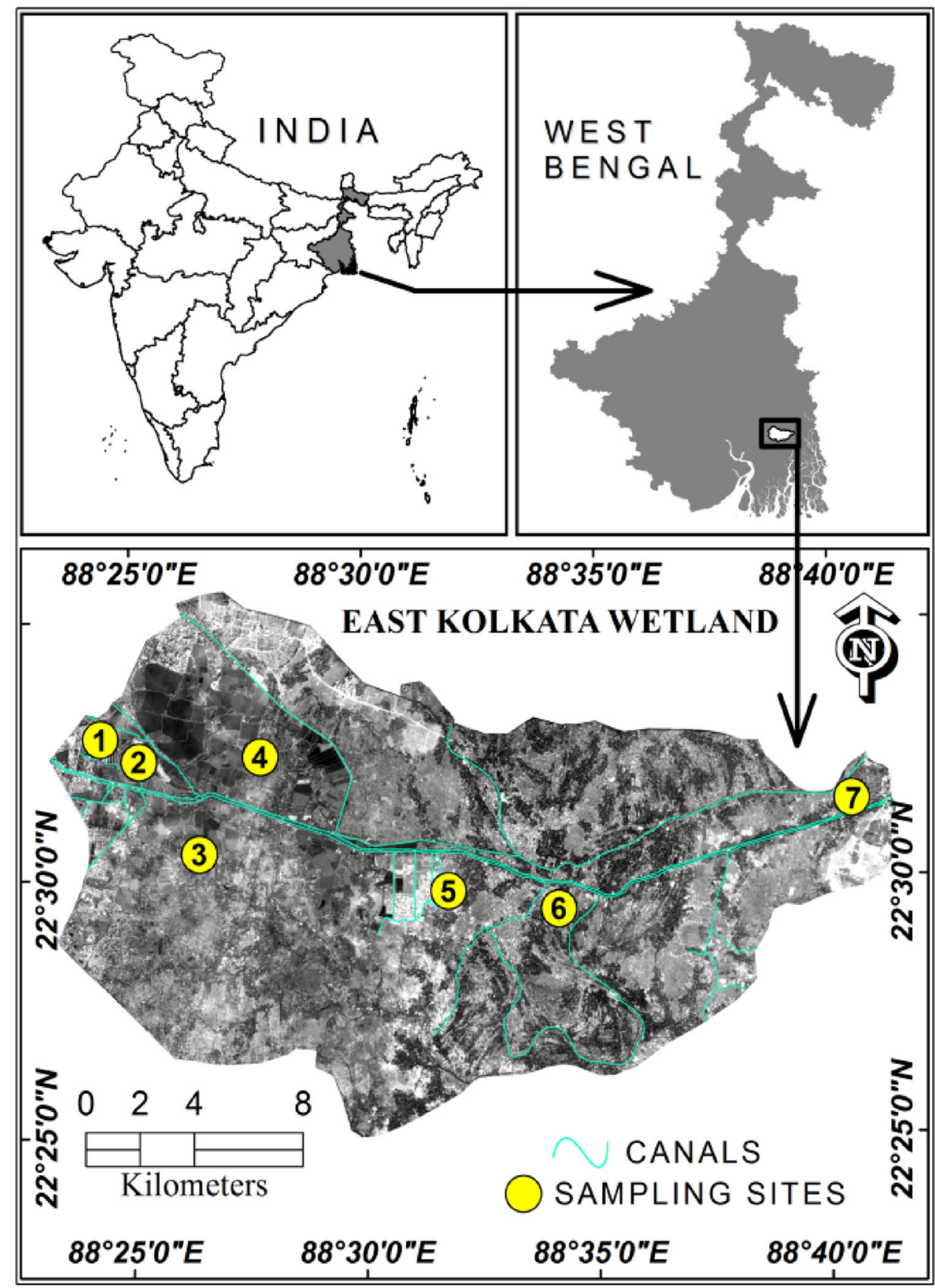

$\hat{Z}\left(s_{0}\right)=\sum_{i=1}^{n} \omega_{i} \phi\left(\left\|s_{i}-s_{o}\right\|\right)+\omega_{(n+1)}$

(where, $\phi(r)$ is a radial basis function, $r$ is Euclidean distance between prediction and sample data location, $r=\left\|s_{i}-s_{o}\right\|$ and $\mathrm{s}_{\mathrm{i}}$ is sample location and $\mathrm{s}_{0}$ is prediction location, $\omega_{i}$ are weights to be estimated where, $i=1,2$, $3, \ldots, n+1)$.

The radial basis function used for spatial gradient mapping of nutrients is Multiquadratic, $\phi(r)=$ $\left(r^{2}+\sigma^{2}\right)^{1 / 2}$. Where, $\sigma$ is optimal smoothing factor which reduced the Root Mean Square error by cross validation.

For the ease of mapping, thematic layers delineating manmade structures, settlements and the wetlands were derived from Indian remote sensing (IRS) satellite: Resourcesat 2 LISS IV image. The image is multispectral with a high resolution of $5.8 \mathrm{~m}$. The cloud free satellite image of the year 2015 was used and after necessary geometric and atmospheric corrections thematic classification was performed. The landcover mapping was done 
using Normalized Differential Vegetation Index-NDVI (Tucker 1979) which is an efficient index for wetland studies (Ozesmi and Bauer 2002). Classification of landcover classes and post classification accuracy was done based on ground based position data acquired using Garmin GPS 72. The thematic map was used for masking the interpolation outputs.

\section{Results and discussion}

EKW receives $\simeq 50,000 \mathrm{~m}^{3} \mathrm{~d}^{-1}$ wastewater from tannery industry, Kolkata municipality and small industrial units and this composite wastewater contains enormous amounts of carbon (Table 1). It is observed that the percentage of organic carbon present in soil is very high at Site 1 and as well as at Site 2 regions. It may be because the raw tannery effluent carrying canal and the tannery effluent-fed fish ponds are present here and with the tannery effluent enormous amount of organic waste specially protein and fat waste (blood, dirt, hair, flesh) are discharged (Pal et al. 2015). Also different carbon containing salts like sodium carbonate, sodium bicarbonate, calcium carbonate, ammonium bicarbonate, which are used in leather processing, are present in the tannery effluent (Pal et al. 2015). The average percentage of SOC at Site 1 is $1.95 \%$ in premonsoon, $1.94 \%$ during the monsoon and $2.25 \%$ in postmonsoon. A moderate percentage of SOC is observed in Site 3 and Site 4 . This is because the tannery effluent, municipal sewage and industrial wastewater which get mixed to the Site 3, are used in Site 4 for pisciculture and agriculture purpose. Mainly the municipal sewage water, which contains huge amount of septic tank discharge and house hold waste, contributes in SOC level of Site 3 and Site 4. From the previous studies (Pal et al. 2013, 2014; Chatterjee et al. 2006) a gradual decrease is recorded from Site 3 onwards. This is possibly attributable to relocation of tanneries at Bantala (Kolkata Leather Complex) i.e. the further entry of tannery effluent may be increased the SOC in Site 5. Whereas, in Site 6 the small and large agricultural runoff canals water and the crop residues of agriculture

Table 1 Mean concentration of six chemical factors present in composite wastewater

\begin{tabular}{lc}
\hline Factors & Concentration $\left(\mathrm{mg} \mathrm{L}^{-1}\right)$ \\
\hline TOC & $348.05 \pm 154.98$ \\
TIC & $95.66 \pm 47.13$ \\
$\mathrm{~F}$ & $0.72 \pm 0.42$ \\
$\mathrm{Cl}$ & $855.59 \pm 688.17$ \\
$\mathrm{NO}_{3}$ & $10.08 \pm 7.54$ \\
$\mathrm{PO}_{4}$ & $4.23 \pm 1.22$ \\
$\mathrm{SO}_{4}$ & $118.11 \pm 93.83$ \\
\hline
\end{tabular}

field contribute to increase the SOC content. Due to strong periodical tidal effect and lack of wastewater sources, minimum amount of SOC is recorded at Site 7 region. Significant $(\mathrm{p}<0.05)$ spatial variations of SOC are noted in EKW (Table 2). In temporal scale due to higher tannery operation and agricultural operation in winter, the carbon load is faintly high in postmonsoon followed by premonsoon- when the decomposition rate of organic materials are high (Fig. 2a-c).

Most of the fluoride $(\mathrm{F})$ present in the soil is insoluble. Depending on the clay and organic carbon content as well as the $\mathrm{pH}$, the retention of $\mathrm{F}$ in the soil is changed (Fuge and Andrews 1988). The $\mathrm{F}$ does not readily get leached from the soil. Total $\mathrm{F}$ concentrations ranges from 20 to $1000 \mu \mathrm{g} \mathrm{g}^{-1}$ in nature, without natural phosphate or fluoride deposits (Liteplo et al. 2002). In EKW the F concentration of all the seven sites are higher than the WHO standard. Hence, animals which take those plants that are grown in the EKW soils have the potential risk of $\mathrm{F}$ toxicity. Thus, the consumption of such plants and animals in the EKW area subsequently can form an important source of $\mathrm{F}$ toxicity for biota. Among the five measured anions in EKW the inorganic $\mathrm{F}$ has noticeable influenced in organic C assimilation in soil. Herrera (2008) has stated that inhibition of soil microorganism's activity by inorganic F, results the high rate of accumulation of soil organic matter. $\mathrm{F}$ also inhibits the methanogenesis process (Janssen and Frenzel 1997), results it reduces the loss of $\mathrm{C}$ through $\mathrm{CH}_{4}$ from EKW. Also $F$ pollution can lead to increase the uptake of aluminium ( $\mathrm{Al}$ ) by plants and the $\mathrm{Al}$ has toxic effects on plants (Arnesen 1997). F also reduces the uptake of cations and interfering metal-ion transport of plants (Weinstein and Alscher-Herman 1982). In EKW area though the F concentration is highest in Site 1 due to use of F-salts in the tanning process but except postmonsoon there are no significant $(\mathrm{p}<0.05)$ spatial variations observed. Whereas, due to the low leachability rate of $F$ and high evaporation rate, the average $\mathrm{F}$ concentration is high in premonsoon followed by monsoon and post monsoon (Fig. 2d-f). It is noticeable that in EKW the directly tannery effluent fed area i.e. in Site 1 and Site 5 significant $(\mathrm{p}<0.05)$ temporal variations take place (Table 2$)$.

Chloride $(\mathrm{Cl})$ is the essential secondary plant nutrient and it is necessary for the proper function of the plants stomatal openings, help in water splitting system of photosynthesis and maintain internal water balance and cation balance (White and Broadley 2001). Though $\mathrm{Cl}$ does not have any direct effect on $\mathrm{C}$ sequestration, still high amount of $\mathrm{Cl}$ suppresses other ions like $\mathrm{NO}_{3}, \mathrm{PO}_{4}, \mathrm{SO}_{4}$ and these ions directly affect the $\mathrm{C}$ mineralization. On the other hand, $\mathrm{Cl}$ is one of the crucial elements which increase the soil salinity, results the increase of $\mathrm{C}$-degrading extracellular enzymes ( $\beta$ - 1,4 -glucosidase, $1,4-\beta$-cellobiosidase, $\beta$-D- 
Table 2 Computed $F$ values of six soil chemical factors within seven different sites and three consecutive seasons from OneWay-ANOVA

\begin{tabular}{|c|c|c|c|c|c|c|c|c|c|c|}
\hline \multirow[t]{2}{*}{ Factors } & \multicolumn{3}{|c|}{ Seasons } & \multicolumn{7}{|l|}{ Sites } \\
\hline & Pre & Mon & Post & Site 1 & Site 2 & Site 3 & Site 4 & Site 5 & Site 6 & Site 7 \\
\hline \multicolumn{11}{|c|}{ Surface soil/bank soil } \\
\hline SOC & $5.92 *$ & $6.26 *$ & $8.86 *$ & 0.85 & 1.34 & 1.86 & 0.47 & 0.38 & 4.07 & 2.38 \\
\hline $\mathrm{F}$ & 3.35 & 1.55 & $3.56^{*}$ & $6.71 *$ & 0.85 & 1.07 & 3.02 & $4.97 *$ & 0.95 & 2.93 \\
\hline $\mathrm{Cl}$ & $37.93 *$ & $4.87 *$ & $7.42 *$ & $11.11 *$ & 3.36 & $10.02 *$ & 2.46 & $5.77 *$ & 2.64 & $305.9 *$ \\
\hline $\mathrm{NO}_{3}$ & $25.03 *$ & $18.42 *$ & $15.81 *$ & $17.30 *$ & $6.23 *$ & $67.84 *$ & $41.79 *$ & $12.04 *$ & $28.39 *$ & 3.57 \\
\hline $\mathrm{PO}_{4}$ & $14.94 *$ & $23.10^{*}$ & $6.00 *$ & $4.73 *$ & 1.17 & 2.12 & $23.19 *$ & $7.05 *$ & 1.11 & 2.77 \\
\hline $\mathrm{SO}_{4}$ & $30.07 *$ & $6.92 *$ & $48.75^{*}$ & $6.32 *$ & $5.34 *$ & $38.98^{*}$ & $21.19 *$ & $5.99 *$ & $21.68 *$ & $11.03 *$ \\
\hline \multicolumn{11}{|c|}{ Soil sediment/bottom soil } \\
\hline SOC & 1.42 & $8.93^{*}$ & $10.97 *$ & 1.21 & $12.44 *$ & $7.28 *$ & $21.88^{*}$ & $14.66^{*}$ & $31.47^{*}$ & 4.17 \\
\hline $\mathrm{F}$ & $9.02 *$ & $29.61 *$ & $3.11 *$ & 0.09 & 2.73 & 1.25 & 3.55 & 1.03 & 2.11 & 2.74 \\
\hline $\mathrm{Cl}$ & $9.50 *$ & $27.39 *$ & $8.71 *$ & $12.10^{*}$ & $4.42 *$ & 3.97 & 1.27 & 2.18 & 3.52 & $6.35^{*}$ \\
\hline $\mathrm{NO}_{3}$ & 2.20 & 1.07 & $14.64 *$ & 5.37 & 0.74 & 0.84 & $26.45^{*}$ & 1.87 & 1.59 & 3.19 \\
\hline $\mathrm{PO}_{4}$ & $3.57 *$ & $29.92 *$ & $120.9^{*}$ & 0.61 & $4.66^{*}$ & 3.33 & $70.48^{*}$ & 0.01 & 4.19 & 3.43 \\
\hline $\mathrm{SO}_{4}$ & $30.25^{*}$ & $4.39 *$ & $17.60 *$ & $15.93 *$ & 2.19 & 1.59 & $35.52 *$ & 2.72 & 2.51 & $7.76^{*}$ \\
\hline
\end{tabular}

The $F$ values mark ' $*$ ' are significant at $p<0.05$ xylosidase, and phenol oxidase) activities. Consequently, a decrease in SOC accumulation, accretion, and $\mathrm{C}$ sequestration rates (Morrissey et al. 2014) are observed. In this present study compared to other sites the $\mathrm{Cl}$ concentration at Site 1 and Site 2 is very high as the raw tannery effluent contains sodium chloride, ammonium chloride which is used in tannery operation called salt-pickling (Table 1). Also the $\mathrm{Cl}$ concentration is recorded also high in Site 7; because this region is under the direct influence by tidal effect of Bay of Bengal. At the intermediate four locationsSite 3 to Site 6 , the $\mathrm{Cl}$ concentration is always less than site 1 and site 7. ANOVA results also show the significant $(\mathrm{p}<0.05)$ spatial variation of $\mathrm{Cl}$ in all seasons (Table 2$)$. In premonsoon the average air temperature is noted above $38{ }^{\circ} \mathrm{C}$, therefore the evaporation rate is consequently high and it results high $\mathrm{Cl}$ concentration in EKW area (Fig. 2g). When the internal soil drainage is good and the rainfall is relatively high in an area, the $\mathrm{Cl}$ leached from the soil profile. So, as EKW is a natural wetland with good soil drainage system in monsoon, due to heavy rainfall, $\mathrm{Cl}$ drips downwards from surface soil and also flushed with the runoff (Fig. 2h). Perhaps due to these reasons during monsoon a marked decrease in $\mathrm{Cl}$ concentration in all seven sites is found. In post-monsoon, most of the areas of EKW are used for agricultural purpose. Thereby, the uptake of $\mathrm{Cl}$ as an essential nutrient by cultivated plants may reduce the $\mathrm{Cl}$ concentration in soil in post monsoon (Fig. 2i). Except Site 2 and Site 6 significant seasonal variations of $\mathrm{Cl}$ are observed in all sites. According to DNRW (2007), Cl concentration over $600 \mathrm{mg} \mathrm{kg}^{-1}$ in surface soil causes toxicity for plants. In the present investigation the surface soil $\mathrm{Cl}$ concentration of most of the area of EKW over threshold level, which may reduces the average plant growth and triggers the C-degrading extracellular enzymes activity, causing the decrease of $\mathrm{C}$ sequestration.

Nitrate $\left(\mathrm{NO}_{3}\right)$ is the major source of nitrogen of plants. The $\mathrm{NO}_{3}$ is stored in vacuoles of plants and took part in protein synthesis. At standard temperature and pressure almost all the inorganic nitrate salts are soluble in water. The $\mathrm{NO}_{3}$ mainly comes from air, soil organic matter, crop residue, fertilizer, rainfall and municipal wastewater (septic tank and lavatories discharge, household water). Here in composite tannery effluent, aluminium nitrate, sodium nitrate, lead nitrate salts which are used in tanning process, are the source of $\mathrm{NO}_{3}$ (Table 1). Due to the direct effect of tannery effluent, $\mathrm{NO}_{3}$ concentration is high in Site 1 and Site 2 and in municipal sewage discharge area i.e. in Site 3 $\mathrm{NO}_{3}$ concentration is high. May be due to the less tanning operation in premonsoon, the $\mathrm{NO}_{3}$ concentration is lower in this season than other two seasons (Fig. 2j). After the monsoon, the agricultural runoff and high rainfall (Salve et al. 2008) may be increase the amount of $\mathrm{NO}_{3}$ (Fig. 2k). On the other hand the leguminous plants also give a contribution in soil $\mathrm{NO}_{3}$ enrichment in post monsoon (Fig. 21). ANOVA results also justify the significant $(p<0.05)$ spatio-temporal variations of $\mathrm{NO}_{3}$ in EKW (Table 2). Griffin (1995) has evaluated that soil $\mathrm{NO}_{3}$ concentration in the range of 25 to $30 \mathrm{mg} \mathrm{kg}^{-1}$ is sufficient for agricultural practice and in EKW area the average $\mathrm{NO}_{3}$ concentration (Figs. $2 \mathrm{j}-1,3 \mathrm{~g}-\mathrm{h}$ ) is much more than that. Though $\mathrm{NO}_{3}$ is favored for crop yields as well as other wetland macrophytes growth and these all together increase the productivity and consequently increases the $\mathrm{C}$ sequestration but excess $\mathrm{NO}_{3}$ created threat for nitrate toxicity (Camago et al. 2005) in agro-pisciculture practices in EKW area. So, 


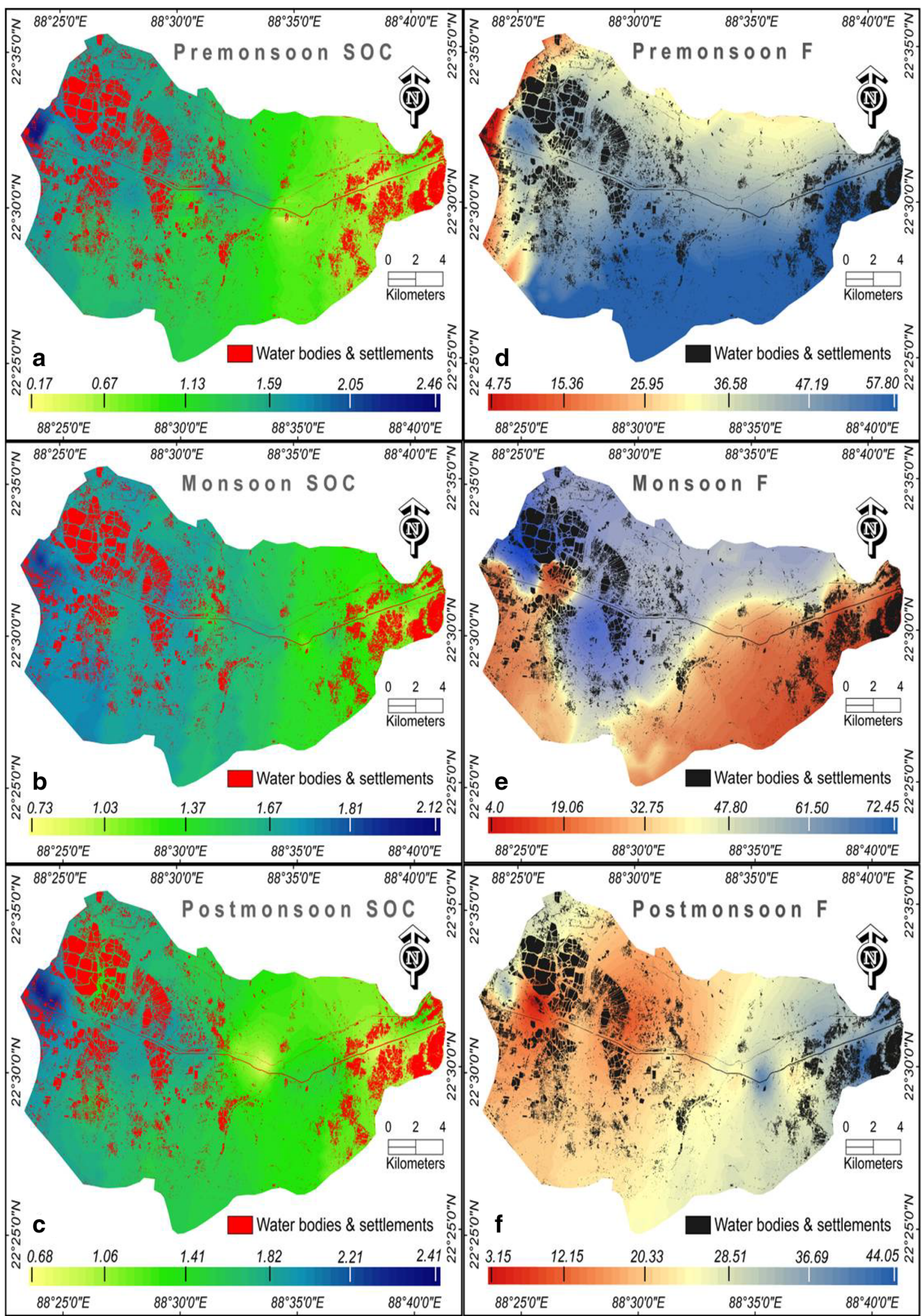


4Fig. 2 a-f Maps of spatial and temporal variations of SOC (\%) and F $\left(\mathrm{mg} \mathrm{kg}^{-1}\right)$ in surface soil of EKW. $\mathbf{g}-\mathbf{l}$ Maps of spatial and temporal variation of $\mathrm{Cl}\left(\mathrm{mg} \mathrm{kg}^{-1}\right)$ and $\mathrm{NO}_{3}\left(\mathrm{mg} \mathrm{kg}^{-1}\right)$ in surface soil of EKW. $\mathbf{m}-\mathbf{r}$ Maps of spatial and temporal variation of $\mathrm{PO}_{4}\left(\mathrm{mg} \mathrm{kg}^{-1}\right)$ and $\mathrm{SO}_{4}\left(\mathrm{mg} \mathrm{kg}^{-1}\right)$ in surface soil of EKW

there is a need for proper management strategies for utilization of composite tannery wastewater in agro-piscicultural practices in near future.

Phosphate $\left(\mathrm{PO}_{4}\right)$ is very important for plant growth and it is involved in numerous key plant functions viz. energy transfer by formation of ATP, photosynthesis, transformation of sugars and starches (Sultenfuss and Doyle 1999). It is the structural component of nucleic acid by which the genetic characteristics are transfer from one generation to the next. It is noted that the raw tannery effluent contains fewer amount of $\mathrm{PO}_{4}$ and mixing with municipal wastewater, which contain high amount of $\mathrm{PO}_{4}$, makes the composite wastewater more productive for agro-piscicultutral practices (Table 1). From our survey, in EKW there are two sources of $\mathrm{PO}_{4}$; (1) point sources: municipal and industrial wastewater and raw tannery wastewater (sodium triphosphate salt) and (2) non-point sources: agricultural runoff (fertilizer, manure, bio-solids, etc.) runoff from parking lots, construction sites and septic systems. In Site 2 and Site 4 the $\mathrm{PO}_{4}$ concentration is high because of the use of $\mathrm{PO}_{4}$ rich fertilizer (super phosphate, ammonium phosphate, thermophos, dicalcium phosphate etc.) and foods in agricultural and piscicultural farming. The municipal sewage of Kolkata city, which contain $\mathrm{PO}_{4}$ from the urban source (Chattopadhyay et al. 2004), get mixed in Site 3, thus the soils of this region contain moderate amount of $\mathrm{PO}_{4}$. But except Site 2 and Site 4 the overall the $\mathrm{PO}_{4}$ concentration is lower in EKW than the standard average $\mathrm{PO}_{4}$ content i.e. $50 \mathrm{mg} \mathrm{kg}^{-1}$ in soil (Sharma et al. 2013). Though significant $(\mathrm{p}<0.05)$ spatial variations is noted in EKW region but in temporal scale the $\mathrm{PO}_{4}$ concentration does not significantly $(\mathrm{p}<0.05)$ vary in all sites (Table 2$)$. From the Fig. $3 \mathrm{i}$ it has been noted that only in the monsoon, $\mathrm{PO}_{4}$ concentration is lower than two seasons. This is possibly due to high precipitation and leaching, the $\mathrm{PO}_{4}$ content is equally distributed throughout the EKW region (Fig. $2 \mathrm{~m}-\mathrm{O}$ ). Overall the average $\mathrm{PO}_{4}$ concentrations in EKW area are very healthy for the agro-pisciculture practices.

Sulfate $\left(\mathrm{SO}_{4}\right)$ usually considers as one of the major plant nutrient. It is the raw material of plant proteins, vitamins and mustered oil glycosides. It also activates certain enzyme system; increases seed oil contain; structural component of the compounds that generate odors and flavors of mustard oil, onion, garlic; catalyst in chlorophyll production; promote nodule formation in legumes and increases the plant growth. Association with organic matter/carbon the $\mathrm{SO}_{4}$ is present in soils. So, the increase of SOC increases the $\mathrm{SO}_{4}$ value in soil. According to Field (1972) on an average $850 \mathrm{mg} \mathrm{kg}{ }^{-1} \mathrm{SO}_{4}$ is present in soils and in the $\mathrm{EKW}$ area the average $\mathrm{SO}_{4}$ value $\left(2239.7 \pm 1778.8 \mathrm{mg} \mathrm{kg}^{-1}\right)$ is more than that. But till date significant evidence of $\mathrm{SO}_{4}$ toxicity on biota has not been found. Only excess $\mathrm{SO}_{4}$ can reduce the uptake of some anions like $\mathrm{NO}_{3}$, molybdenum $\left(\mathrm{MoO}_{4}\right)$ and it decreases the soil $\mathrm{pH}$, which have negative impact on agricultural productivity. The main source of sulfate in EKW are the sulfate salt like aluminum sulfate, chromium sulfate, etc. which are massively used in tanning operations. Another source of $\mathrm{SO}_{4}$ is the municipal sewage contains detergents which consist of organosulfate and sodium sulfate. Possibly for these two sources in the Site 1, Site 2 and Site 3 the sulfate concentration is higher than other sites. The reintroduction of tannery effluent in the Site 5 and the tidal effect in Site 7 results moderate $\mathrm{SO}_{4}$ concentration in soil. In the premonsoon the average air temperature is recorded above $38{ }^{\circ} \mathrm{C}$, therefore the rate of evaporation is high consequently, results a high $\mathrm{SO}_{4}$ concentration is detected in this time (Fig. 2p). Owing to heavy precipitation in monsoon the $\mathrm{SO}_{4}$ drips downwards from surface soil and is also flushed with runoff water (Fig. 2q). Though sufficient amount of $\mathrm{SO}_{4}$ is present in the EKW soil, but due to the lack of knowledge and soil testing facilities, the farmers are used $\mathrm{SO}_{4}$ containing salt (ammonium sulfate, potassium sulfate, ammonium polysulphate, gypsum etc.) in postmonsoon as a fertilizer in agricultural farming (Fig. 2r). ANOVA results validate the significant $(\mathrm{p}<0.05)$ spationtemporal variations of $\mathrm{SO}_{4}$ (Table 2).

Geostatistical methods produce only maps of the surface soil, to delineate a soil profile of EKW. But to know the overall chemical properties of soil the bottom soils of water bodies, canals are also analyzed. Because due to direct effect of wastewater the organic and chemicals are settled down for mineralization into the bottom soil and leached to the surrounded area. The soil organic carbon load in Site 1 is the highest and in Site 7 it is the lowest in all these seasons. Except premonsoon the SOC significantly $(\mathrm{p}<0.05)$ differs spatially (Table 2$)$. In temporal scale, depending upon the municipal sewage mixing, vegetation cover, soil settlement rate, tannery effluent discharge, the SOC concentration is varied and it is recorded the lowest in monsoon. Because due to the heavy rainfall in monsoon the soils become flushed out through erosion and stirring (Fig. 3a, b). Except Site 1 and Site 7 SOC content differ significantly in temporal scale. Unlike SOC, other chemical variables in both bank and bottom soil are also relatively high in premonsoon. The concentration of $\mathrm{F}$ and $\mathrm{Cl}$ is high (except Site 4) in premonsoon than other two seasons (Fig. 3c-f). On an average the $\mathrm{NO}_{3}$ and $\mathrm{PO}_{4}$ are slightly high in monsoon than other two seasons (Fig. $3 g-j$ ). In case 


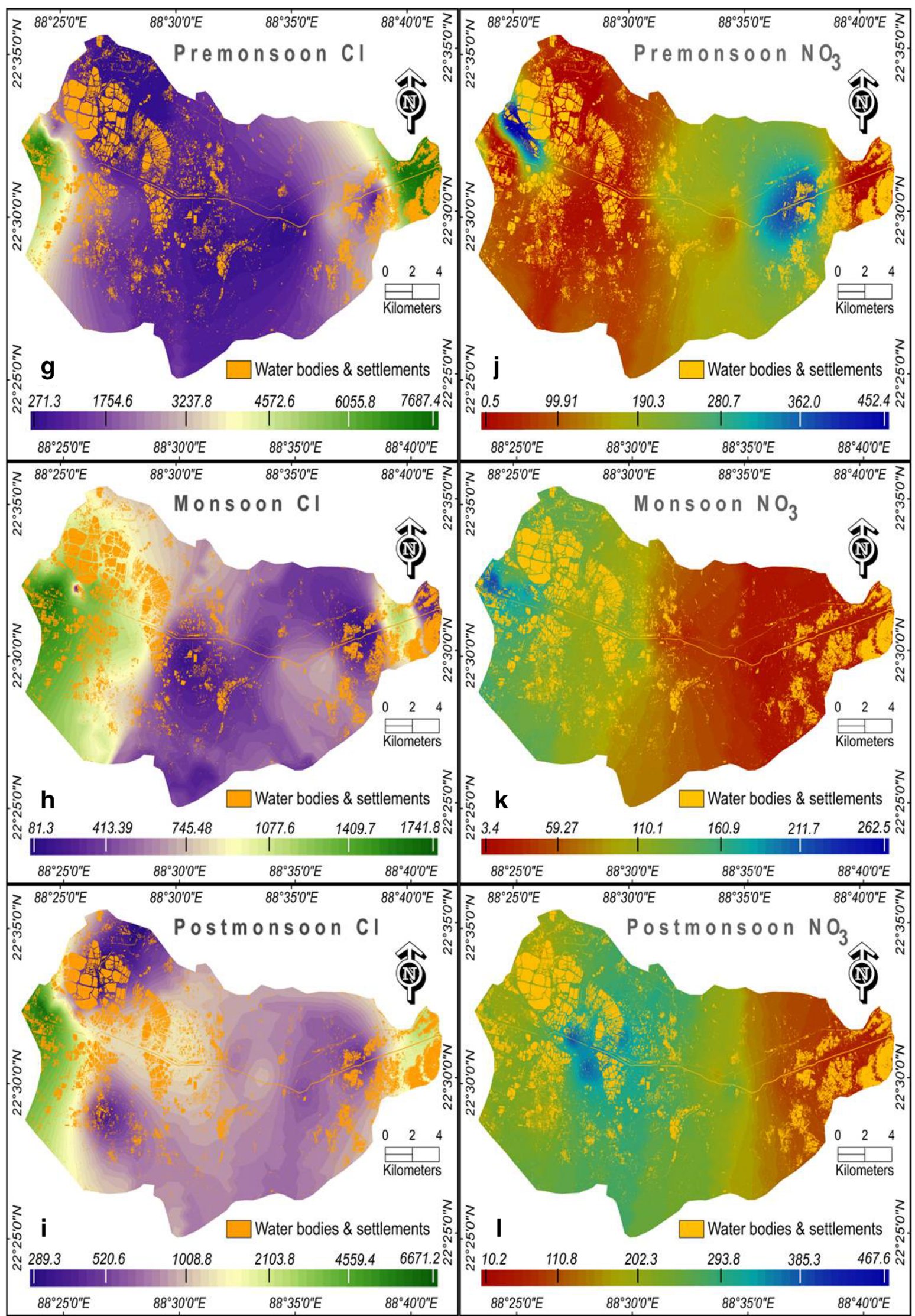

Fig. 2 continued 


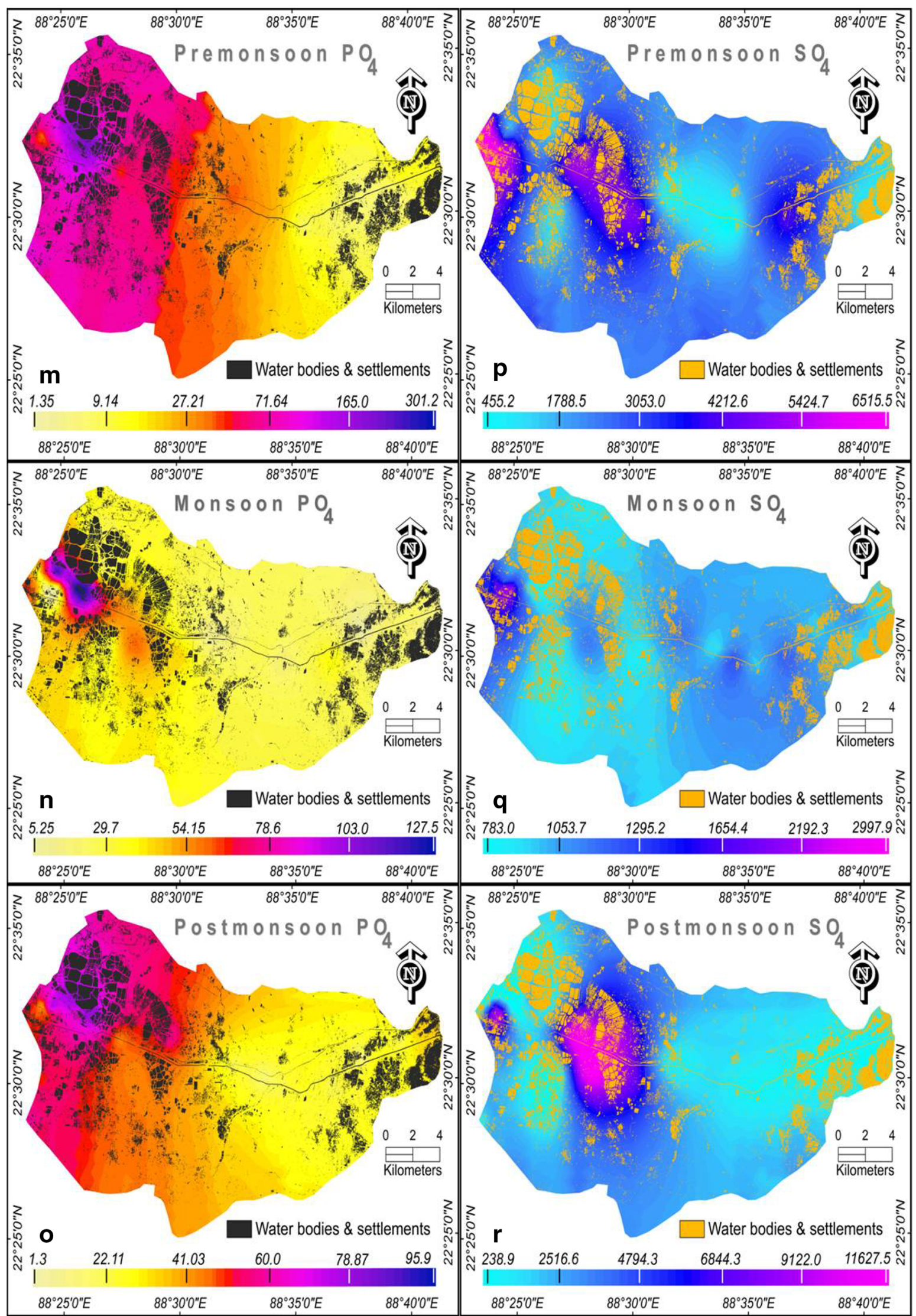

Fig. 2 continued 


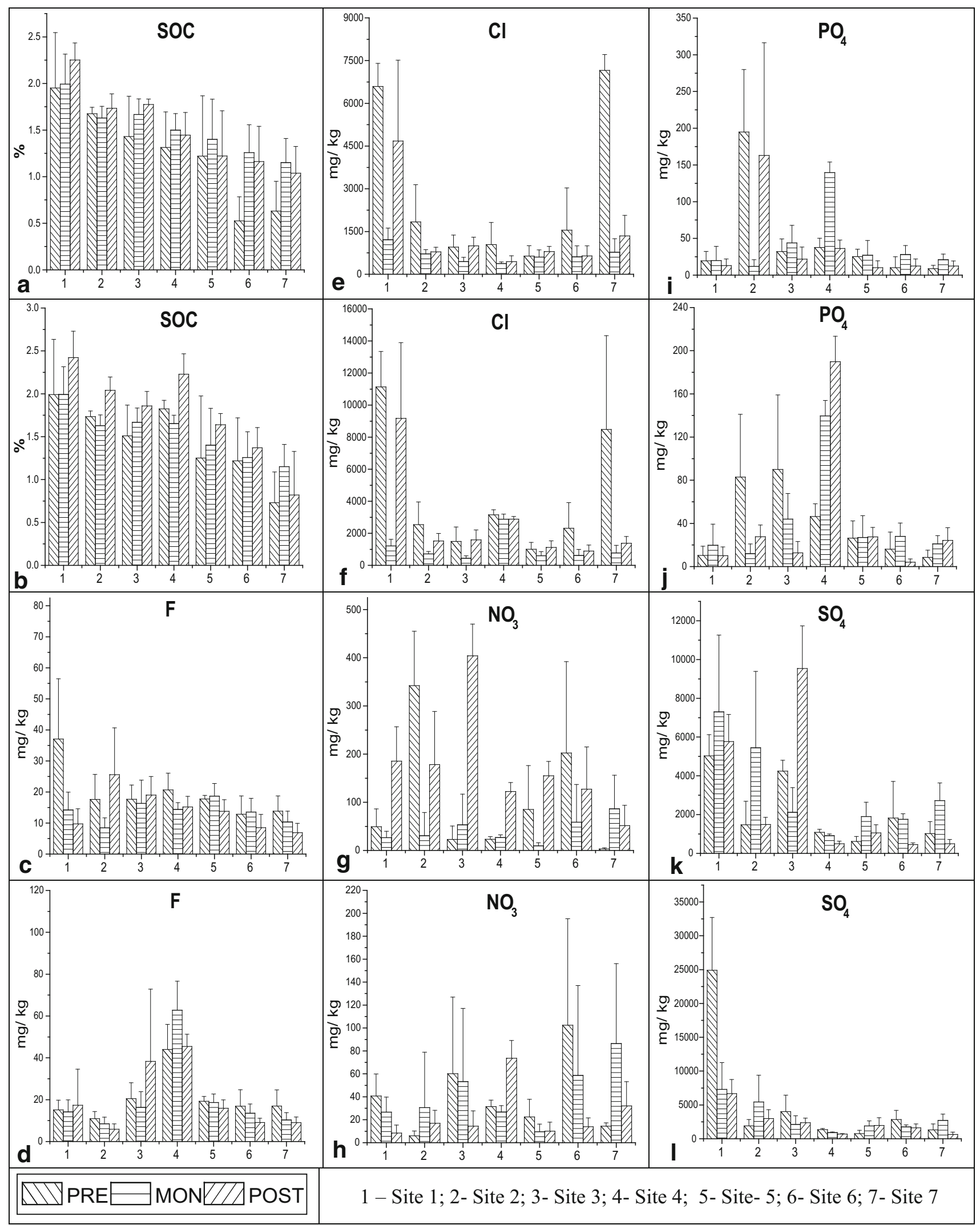

Fig. 3 a-l Graphical representation of temporal differences between bank soils with bottom soils of seven different sites for six different factors 
of $\mathrm{SO}_{4}$ only, in Site 1 distinguishable variation among the three seasons is noticed. But in the other six sites, the $\mathrm{SO}_{4}$ concentration does not differ seasonally (Fig. 3k, 1). Except $\mathrm{NO}_{3}$ in premonsoon and monsoon, spatially all the factors are varied significantly ( $\mathrm{p}<0.05$; Table 2$)$. It should be mentioned here that graphical representations of the data given here, are constructed on the mean of the seven study sites for 2 years. This can be noted that during sampling, wastewater discharge time, amount of wastewater, tidal activities affected the data set for the spatio-temporal changes of concentrations of variables under study, so, the standard deviation of the mean data set are high in some cases.

Apart from this in case of submerged soils, a thin oxic zone is present in the uppermost layer of sediment, whereas the rest part remains anoxic due to low oxygen diffusion. Mendelssohn et al. (1999) and Silvola et al. (1996) have reported that in such anoxic sediments of wetland ecosystem, a diverse group of microorganisms are present and they can hydrolyzed, fermented and terminally oxidized the organic compounds. These microbes can utilize $\mathrm{NO}_{3}$, $\mathrm{PO}_{4}$, and $\mathrm{SO}_{4}$ as alternative electron acceptors for those biochemical processes. Reddy and Delaune (2008) have also stated that such electron acceptors have a profound effect on various biogeochemical properties regulating organic matter mineralization and transformation of organic $\mathrm{C}$.

\section{Conclusions}

It is obtained from the present study that the soil of EKW store high amount of carbon and composite tannery wastewater is the main contributor for that. The efficiency of carbon storage of the EKW ecosystem, gives an extra count towards the conservation and restoration of this fragile ecosystem. The retention of the anions-cations and availability of them are depends on SOC and vice versa. That means depending upon the concentration variations of all these anions in the present study of EKW, the carbon assimilation, mineralization and sequestration in soil are sustained.

The present study shows that the composite tannery wastewater has great influence on the soil chemical properties and it enhances the concentration of anions in EKW soil. This study is revealed that the waste products of Kolkata city and the tannery industry is the wealth of EKW ecosystem. Though the anions like $\mathrm{F}, \mathrm{Cl}$ and $\mathrm{SO}_{4}$ are present in very high concentration in EKW and this may decrease the ecosystem production. Also due to the antagonistic natures of these anions may reduce their uptake through plants. So, the control on waste release into EKW ecosystem will minimized the all these adverse effects. As the results and the profile maps give clear information to the farmer about the anions/nutrient concentration of EKW area. It is advised to the farmers except $\mathrm{PO}_{4}$, others essential nutrients like $\mathrm{F}, \mathrm{Cl}, \mathrm{NO}_{3}, \mathrm{SO}_{4}$ are present in sufficient amount in EKW soil. Thus no need to use extra fertilizer for those anions and it will reduce the fertilizer cost and the end benefits go to the farmers. Also this study surely guides to take proper management strategy, which will upgrade the economical as well as the ecological value of EKW Ecosystem. Moreover in the context of carbon sequestration this present study will surely urge the EKW management authority to claim the carbon credit and it will help to execute conservation plans regarding EKW which will boost up the present condition of rural artisans.

Acknowledgments First and last author thankfully acknowledges University Grant Commission, Govt. of India. Authors express their thanks to Prof. Sanjoy Chakraborty, Dr. Anjan Biswas and Dr. Anulipi Aich, GCELT, Kolkata, for their valuable support in this study.

\section{References}

Alexakis DD, Sarris A (2014) Integrated GIS and remote sensing analysis for landfill sitting in Western Crete, Greece. Environ Earth Sci 72:467-482

Arnesen AKM (1997) Availability of fluoride to plants grown in contaminated soils. Plant Soil 191:13-25

Bhunia G, Shit PK, Maiti R (2016) Spatial variability of soil organic carbon under different land use using radial basis function (RBF). Model Earth Syst Environ 2:1-8. doi:10.1007/s40808015-0070-x

Bishop CM (1995) Neural networks for pattern recognition. Oxford Press, Oxford, p 482

Bruland GL, Richardson CJ (2005) Spatial variability of soil properties in created, restored and paired natural wetlands. Soil Sci Soc Am J 69:273-284

Camago JA, Alonso A, Salamanca A (2005) Nitrate toxicity to aquatic animals: a review with new data for freshwater invertebrates. Chemosphere 58(9):1255-1267

Chatterjee S, Chattopadhyay B, Mukhopadhyay SK (2006) Trace metal distribution in tissues if cichlids (Oreochromis niloticus and $O$. mossambicus) collected from wastewater-fed fishponds in East Kolkata wetlands a Ramsar site. Acta Ichthyol Piscat 36(2):119-1250

Chattopadhyay B, Chatterjee S, Mukhopadhyay SK (2004) Seasonality in physico-chemical parameters of tannery wastewater passing through the East Kolkata wetland ecosystem. J Soc Leath Tech Chem 88(1):27-36

Chiles J, Delfinder P (1999) Geostatistics. Modeling spatial uncertainty. Wiley, New York, p 695

Corstanje R, Grunwald S, Reddy KR, Osborne TZ, Newman S (2006) Characterization of the spatial distribution and uncertainty of soil properties in water conservation area 1, South Florida. J Environ Qual 35:938-949

Cressie N (1993) Statistics for spatial data. Wiley, New York, p 900

DeBusk WF, Newman S, Reddy KR (2001) Spatio-temporal patterns of soil phosphorus enrichment in Everglades Water Conservation Area 2A. J Environ Qual 30:1438-1446 
Eaton AD, Clesceri LS, Greenberg AE (2005) Standerd methods of the examination of water and wastewater, 21st edn. American Public health Association, Washington DC

Field CW (1972) Sulfur: element and geochemistry. In: Fairbridge RW (ed) The encyclopedia of geochemistry and environmental sciences, Van Nostrand Reinhold, New York, pp 1142-1148

Fuge R, Andrews MJ (1988) Fluorine in the UK Environment. Geochem Health 96:10

Griffin G (1995) Recommended soil nitrate N tests. In: Sims JT, Wolf A (eds) Recommended soil testing procedures for the northeastern United States, Northeast Regional Bull 493. University of Delware, Newark, pp 27-35

Grunwald S (2005) What do we really know about the space-time continuum of soil-landscapes. In: Grunwald S (ed) Environmental soil-landscape modeling-geographic information technologies and pedometrics. CRC Press, New York, pp 3-36

Goswami RA, Aich A, Pal S, Chattopadhyay B, Mukhopadhyay SK (2013) Antioxidant response to oxidative stress in zooplankton thrived in wastewater-fed ponds in East Calcutta Wetland Ecosystem, a Ramsar site. Toxicol Environ Chem 95:627-634

Herrera VLO (2008) Removal of perflurooctane sulfonate and related compounds from industrial effluent. Thesis $\mathrm{PhD}$. University of Arizona, USA, pp 317-321

Jackson PE (2000) Ion chromatography in environmental analysis. In: Meyers RA (ed) Encyclopedia of analytical chemistry. Wiley, Chichester, pp 2779-2780

Janssen PH, Frenzel P (1997) Inhibition of methanogenesis by methyl fluoride: studies of pure and defined mixed cultures of anaerobic bacteria and archaea. Appl Environ Microbiol 63(11):4552-4557

Liteplo R, Gomes R, Howe P, Malcolm H (2002) Fluorides; environmental health criteria 227. World Health Organization, Geneva

Mendelssohn IA, Sorrell BK, Brix H, Schierup HH, Lorenzen B, Maltby E (1999) Controls on soil cellulose decomposition along a salinity gradient in a Phragmites australis wetland in Denmark. Aquat Bot 64:381-398

Morrissey EM, Gillespie JL, Morina JC, Franklin RB (2014) Salinity affects microbial activity and soil organic matter content in tidal wetlands. J Environ Microbiol 20(4):1351-1362

Ozesmi SL, Bauer ME (2002) Satellite remote sensing of wetlands. Wetlands Eco Manag 10:381-402

Pal S, Chattopadhyay B, Mukhopadhyay SK (2013) Variability of carbon content in water and sediment in relation with physico- chemical parameters of East Kolkata Wetland Ecosystem: a Ramsar Site. NeBIO J. 4(6):70-75

Pal S, Chattopadhyay B, Mukhopadhyay SK (2014) Oxidative response of wetland macrophytes in response to contaminants of abiotic components of East Kolkata wetland ecosystem. Limnol Rev 14(2):101-108

Pal S, Chattopadhyay B, Mukhopadhyay SK (2015) Assessment of carbon contribution to the East Kolkata Wetland Ecosystem (Ramsar Site: 1208) by different Leather Producing Units of Calcutta Leather Complex area, Part I. J Soc Leather Technol Chem 99(1):1-7

Pal S, Chattopadhyay B, Mukhopadhyay SK (2016) Importance of agriculture and crop residues in carbon sequestration and nutrient enrichment at agricultural farms of East Kolkata Wetland area, a Ramsar site. Curr Sci 110:1330-1337

Reddy KR, Delaune RD (2008) Biogeochemistry of Wetlands. Taylor \& Francis, CRC Press, Boca Raton, pp 119-134

Richardson CJ, Reiss P, Hussain NA, Alwash AJ, Pool DJ (2005) The restoration potential of the Mesopotamian marshes of Iraq. Science 307:1307-1311

Salve PR, Maurya A, Wate SR, Devotta S (2008) Chemical composition of major ions in rainwater. Bull Environ Contam Toxicol 80(3):242-246

Schloeder CA, Zimmerman NE, Jacobs MJ (2001) Comparison of methods for interpolating soil properties using limited data. Soil Sci Soc Am J 65:470-479

Sharma SB, Sayyed RZ, Trivedi MH, Gobi TA (2013) Phosphate solubilizing microbes: sustainable approach for managing phosphorus deficiency in agricultural soils. Springerplus 2:587. doi: $10.1186 / 2193-1801-2-587$

Silvola J, Alm J, Ahlholm U, Nykaenen H, Martikainen PJ (1996) $\mathrm{CO}_{2}$ fluxes from peat in boreal mires under varying temperature and moisture conditions. J Ecol 84:219-228

Sultenfuss JH, Doyle WJ (1999) Phosphorus for agriculture. Better Crops 83(1):6-7

Tucker CJ (1979) Red and photographic infrared linear combinations for monitoring vegetation. Rem Sens Environ 8(2):127-150

Weinstein LH, Alscher-Herman R (1982) Physiological responses of plants to fluorine. In: Unsworth MH, Ormrod DP (eds) Effects of gaseous air pollution in agriculture and horticulture. Butterworth, London, pp 139-167

White PJ, Broadley MR (2001) Chloride in soils and its uptake and movement within the plant: a review. Ann Bot Lond 88(6):967-988 